\title{
KILKA UWAG O POKOLENIOWEJ SYTUACJI WSPÓŁCZESNEJ POLSKIEJ MŁODZIEŻY
}

\section{WPROWADZENIE}

Dynamiczny przebieg najpierw globalnego kryzysu finansowego (20072008), a później światowego załamania ekonomicznego (którego konsekwencje/kontynuacje doświadczamy do dzisiaj) w realny i zarazem symboliczny sposób zmodyfikowały proces wymiany pokoleń (nie tylko zresztą w naszym kraju). Opisując parę lat temu cechy charakterystyczne Europejskich Poszukiwaczy, polskiej grupy pokoleniowej, którą tworzyły/tworzą osoby urodzone mniej więcej w latach 1983-89, sugerowałem, że trwający już wówczas światowy kryzys najprawdopodobniej przyśpieszy proces wymiany pokoleń, kończąc czas dominacji Europejskich Poszukiwaczy. Na potrzeby analiz światów pokoleń przeprowadzanych na wykładach zacząłem potencjalnie nową grupę pokoleniową roboczo nazywać Dziećmi Kryzysu. W ciagu ostatnich lat stopniowo krystalizował się jednak coraz wyraźniejszy zbiór cech nowej pokoleniowej sytuacji, który z przestrzeniami efektów kryzysu ekonomicznego ma związki jedynie pośrednie. Można w tym miejscu, jak sądzę, zaryzykować stwierdzenie, że kryzys ekonomiczny bardziej towarzyszy pokoleniowej sytuacji współczesnej polskiej młodzieży, stanowiąc zauważalne jej tło, aniżeli jest jedna z jej przyczyn sprawczych. Nie zmienia tego też fakt pewnej medialnej popularności sformułowania „dzieci kryzysu” czy „pokolenie kryzysu”. Najprościej rzecz ujmując, można powiedzieć, że kryzys ekonomiczny nie stał się dla młodych Polaków ani wydarzeniem pokoleniowym, ani nie znalazł też swojego wyraźnego miejsca w ich pokoleniowej sytuacji, co - w moim przekonaniu - dyskwalifikuje termin Dzieci Kryzysu jako ewentualną nazwę nowej grupy pokoleniowej w Polsce.

Zanim przejdę do próby wstępnej charakterystyki cech nowej sytuacji pokoleniowej polskiej młodzieży, konieczne będzie krótkie przypomnienie systematyzacji stosowanego przeze mnie modelu pojęciowego.

W przyjmowanej perspektywie badawczej, sytuujaccej moje analizy w orientacji kulturowej postrzegania pokolenia jako kategorii analitycznej w socjologii, pokoleniem jest zbiorowość (grupa) ${ }^{1}$ o cechach kategorii rówieśniczej, po-

${ }^{1} \mathrm{~W}$ ramach orientacji kulturowej postrzegania pokolenia rozumiane jest ono zarówno jako szersza zbiorowość (krąg społeczny, zbiór kręgów), jak i grupa społeczna. Ze względu na brak miejsca na rozwinięcie tej myśli zmuszony jestem odesłać czytelnika do innych źródeł (zob. W. Wrzesień, Europejscy Poszukiwacze. Impresje na temat wspótczesnego pokolenia polskiej mło- 
wstająca na bazie wspólnoty myśli i zachowań stanowiących reakcję na „nowa sytuację historyczna”, a nie proste następstwo wydarzeń historycznych. O jego zaistnieniu świadczy stan pokoleniowości ${ }^{2}$, na który składa się tożsamość społeczna pokolenia, w ostatnich latach raczej śladowe poczucie pokoleniowej przynależności oraz zbiór cech identyfikacyjnych pokolenia.

Każde pokolenia posiada swój „punkt krytyczny”, gdy mniej lub bardziej wyraźnie zaznacza swoją obecność i jest bez trudu przez zewnętrznych obserwatorów dostrzegane. To okres kształtowania tożsamości społecznej pokolenia, który przypada na przedział mniej więcej od 19 do 26 roku życia. Czas najsilniejszej pokoleniotwórczej aktywności, kiedy oprócz naszej osobowości i indywidualnej tożsamości kształtujemy też społeczną tożsamość naszego pokolenia. Tożsamość społeczna pokolenia to symboliczna przynależność do poszczególnych czasowych i terytorialnych segmentów rzeczywistości społecznej, w których manifestują się cechy identyfikacyjne kolejnych grup i kręgów pokoleniowych, odpowiedzialne za styl życia młodzieży danego miejsca i czasu. To nic innego jak „tu i teraz naszej młodości”, które przeżywamy prawie wszyscy, będąc młodymi. Tymczasem gdy uświadomimy sobie oryginalność naszej pokoleniowej tożsamości, doświadczamy poczucia pokoleniowej przynależności, na którą składa się: a) poczucie wspólnoty doświadczeń, jakie moga w mniejszym lub większym stopniu wyznaczać ścieżki życiowej kariery (np. wojny, kryzysy ekonomiczne, rewolucje, migracje itp.); b) poczucie wspólnoty interesów, norm, wartości i wzorów zachowań, manifestujące się w realizowanym stylu życia (który odróżnia nas zarówno od starszych, jak i od młodszych) oraz c) poczucie solidarności.

Poczucie pokoleniowej przynależności to pokoleniowość w sensie subiektywnym, wewnętrznym - świadomość uczestnictwa w kształtującym się pokoleniu. Natomiast tożsamość społeczna pokolenia jest faktem obiektywnym, zbiorem cech, które wyróżniają daną zbiorowość czy grupę w procesie wymiany pokoleń. To zewnętrzna oznaka pokoleniowości, a poznajemy ja poprzez manifestowane w stylu życia młodzieży cechy identyfikacyjne własnych grup pokoleniowych i szerszych pokoleniowych zbiorowości.

Cechy identyfikacyjne młodzieży to cechy „umiejscawiające w czasie” kolejne wcielenia kultury młodzieżowej, do których zaliczam: normy, wartości, wzory, wzorce, zestawy znaków i symboli, które w zależności od sytuacji społecznej moga - wszystkie razem lub tylko niektóre z nich - wpływać na opinie, postawy i podejmowane działania. Cechy te tworzą bardziej złożone struktury, odpowiedzialne za zróżnicowania takich sfer aktywności jednostek, jak: praca, czas wolny, uczestnictwo w kulturze, relacje pomiędzy bliskimi generacjami ${ }^{3}$ i moda.

dzieży, PWN, Warszawa 2009; idem, Jednostka-rodzina-pokolenie. Studium relacji międzypokoleniowych $w$ rodzinie, WN UAM, Poznań 2003).

${ }^{2} \mathrm{~W}$ swoich analizach nawiązuję do terminu i koncepcji Jana Garewicza, Pokolenie jako kategoria socjofilozoficzna, „Studia Socjologiczne” 1983, nr 1, chociaż przyjmowane przeze mnie stanowisko (szerzej omawiam je gdzie indziej - zob. W. Wrzesień, Europejscy Poszukiwacze..., passim) od stanowiska Garewicza się różni.

${ }_{3}$ Bliska generacja to obok pokoleniowej elity jedna $\mathrm{z}$ form grup pokoleniowych. Bliskie generacje swoim zasięgiem obejmują wszystkich przedstawicieli kilku roczników i są kolejnymi, następującymi po sobie ogniwami, odpowiedzialnymi za ciagłość procesu wymiany pokoleń. To zbiorowość o cechach grupy rówieśniczej o maksymalnym przedziale wieku zamykającym się 
We wskazanych powyżej analitycznych obszarach tworzy się (lub nie $\left.{ }^{4}\right)$ mniej lub bardziej wyrazista pokoleniowość młodych, stymulowana zbiorem cech pokoleniowej sytuacji danego miejsca i czasu. Zgodnie z założeniami teorii pokoleń każde pokolenie ma swoja pokoleniotwórczą sytuację, a jedynie sporadycznie pokoleniowe wydarzenie - wspólne pokoleniowe przeżycie, jak pisał Jan Garewicz ${ }^{5}$ (np. wojnę, rewolucję, kryzys ekonomiczny, transformację ustrojowa, ale też doświadczenia czasu zabawy i czasu pracy, wydarzenia medialne czy formy uczestnictwa w kulturze). Wskazując czynniki pokoleniotwórcze wybranych grup czy zbiorowości, preferuję stosowanie terminu pokoleniowa sytuacja, gdyż pokoleniowe wydarzenia przydarzają się tylko nielicznym pokoleniom, a pozostałe kształtują się w następstwie splotu wydarzeń, zjawisk i procesów. Określenie „sytuacja” odzwierciedla je zdecydowanie precyzyjniej.

Pokoleniowa sytuacja współczesnej polskiej młodzieży jest dość szczególna i stanowi efekt zarówno przemian w skali makro, do których należy zaliczyć dominację kultury konsumpcyjnego kapitalizmu, szybki skok cywilizacyjny (głównie rozwój technologii komunikacyjnych), globalizację, akcesję do UE, jak i mikro - dotychczas niewystępujące w podobnej skali zmiany wzorów socjalizacyjnych ${ }^{6}$.

Na pokoleniową sytuację interesujących nas dzisiaj młodych Polaków (roczniki 1990-1997) ${ }^{7}$, przypuszczalnie stanowiących pierwsze kohorty nowej grupy pokoleniowej, składają się przede wszystkim trzy elementy:

1) socjalizacyjne „wykorzenienie z historii”,

2) nieustanne poddawanie niespotykanemu dotychczas, intensywnemu, wieloźródłowemu wpływowi bodźców zewnętrznych oraz

3) fakt, że żyje w świecie zróżnicowanych form uzależnień i im ulega. Przyjrzyjmy się ich niuansom.

w granicach 5-8 lat. Szerzej jej opisem zajmuję się gdzie indziej (zob. W. Wrzesień, Jednostka..., passim; idem, Europejscy Poszukiwacze..., passim).

${ }^{4}$ W historii mogą pojawiać się takie okresy, w których o kształtowaniu się pokoleń w zasadzie trudno jest lub nie powinno się w ogóle mówić (zob. H. Świda-Ziemba, Wartości egzystencjalne młodzieży lat dziewięćdziesiatych, ISNS UW, Warszawa 1999; J. Garewicz, op. cit.; W. Wrzesień, Czy pokoleniowość nam się nie przydarzy? Kilka uwag o współczesnej polskiej młodzieży, „Nauka” 2007, nr 3, s. 131-151.

${ }^{5}$ J. Garewicz, op. cit.

${ }^{6}$ Szerzej omawiam je gdzie indziej (zob. W. Wrzesień, Modyfikacje wzorów socjalizacyjnych w rodzinie w czasach nałogowych konsumentów, „Ruch Prawniczy, Ekonomiczny i Socjologiczny” 76, 2014, z. 3, s. 261-280).

${ }^{7}$ Granice grup pokoleniowych (bliskich generacji) maja relatywnie elastyczny charakter. Szybkie przemiany społeczne przyśpieszają pojawianie się nowych bliskich generacji i powodują zawężanie ich granic, natomiast stabilizacja systemu społecznego sprzyja poszerzaniu ram bliskich generacji. Dokładne wskazanie granic następujących po sobie ogniw w procesie wymiany pokoleń w zasadzie jest możliwe dopiero wówczas, gdy ostatnie zaliczane przez nas do wybranej bliskiej generacji roczniki wyjdą z okresu najintensywniejszej pokoleniotwórczej aktywności, czyli osiagna wiek 27 lat. Oczywiście jest to próg symboliczny i nie należy traktować go dosłownie. Osoby starsze nadal manifestują w codzienności stylu życia cechy identyfikacyjne własnych grup pokoleniowych, lecz stopniowo ich intensywność przeważnie ulega osłabieniu i zmienia swój charakter. Sukcesywnie staje się coraz bardziej pokolniowością dorosłości i ustępuje miejsca nowej młodzieżowej pokoleniowości, która zaczyna dominować na rynku pokoleń, przyciagając zreszta nierzadko uwagę mediów, naukowców, polityków. 


\section{SOCJALIZACYJNE „WYKORZENIENIE Z HISTORII”}

Interesujacy nas młodzi nie znają PRL (urodzili się po 1989 r.), lecz to dorośli pamiętający go odpowiedzialni sa za szczególne postawy i usytuowanie dzisiejszej młodzieży w biegu historii. Dorośli właściwie wyrzucili PRL do kosza, odcięli się od tamtej Polski, odkreślili ja grubą kreską i w konsekwencji powstała luka. Symbolicznemu przerwaniu uległ proces transmisji pokoleniowej wiedzy historycznej pomiędzy pokoleniami. Dorośli zaczęli wdrukowywać młodzieży brak szacunku dla nieodległej w czasie przeszłości (co prawda jej fragmentu, ale bezpośrednio sąsiadującego z teraźniejszościa). Nikt wcześniej młodych do niedawnej przeszłości nie socjalizował w taki sposób. Nawet prób indoktrynacji, podejmowanych przez władzę ludową z lat stalinizmu, w większości polska młodzież wcale nie traktowała poważnie ${ }^{9}$.

Za proces, wyrwania” młodych z historii w znacznym stopniu odpowiedzialni sa rodzice, ale również nauczyciele i media. W efekcie młodzi zachowują się trochę tak, jakby czas zaczynał się od nich. Pozornie dobrze się czują i świetnie sobie radza, ale de facto taki stan przyczynia się do generowania poczucia niepewności i zagubienia. Oni sa zagubieni. Młodym brakuje dziś oparcia w przeszłości i (paradoksalnie) brakuje im też przyszłości - nie odczuwają komfortu psychicznego, wybiegajac myślami w przyszłość. Czują się zawieszeni w próżni. Zawsze nieznana przyszłość, dzisiaj bywa odczuwana przez młodych jako niepewna, a stan ten modyfikuje ich codzienność.

Współczesna młodzież to młodzież „nowej” Polski, Polski po 1989 r., a mówiąc precyzyjniej: po 2000 - wtedy procesy kształtujące sytuację pokoleniowa dzisiejszej młodzieży uległy intensyfikacji. Młodzi pierwszej dekady III RP to dzisiaj 40-latkowie i ich (młodzieżowy) czas miną, a teraźniejsza młodzież jest zupełnie inna. Polska sprzed 1989 r. to dla nich zamierzchła historia, która traktuja jak coś niemal nierealnie odległego, nie tylko w czasie. Wyraźnie dystansuja się od tego, co przeszłe, i nierzadko łaczą z tym oceny wartościujące. Dzisiejsza młodzież w zasadzie całkowicie odcina się od czasów przed $1989 \mathrm{r}$., a swoją współczesność (Polskę po 1989 r.) traktuje jak początek nowej ery, powstałej nie na gruzach przeszłości, lecz w absolutnym oderwaniu od niej. Jednoznacznie negatywna ocena całej rzeczywistości PRL, z którą młodzi stykają się od dzieciństwa (w domu rodzinnym, szkole), przyczyniła się do zaistnienia sytuacji, w której odrzucili oni cały okres czterdziestopięcioletniej historii Polski, łącznie ze wszystkimi, którzy wtedy żyli. To wyraźna niepomyślność procesu socjalizacji - młodzi tak jak nie szanuja przeszłości, tak też podobnie odnoszą się do ludzi wówczas żyjących. Przeszłość nie napawa ich dumą. Czasy ich rodziców i dziadków to dziwna i wroga rzeczywistość, o której lepiej zapomnieć.

Wydaje się również, chociaż jest to na razie wstępnie formułowana hipoteza, że wykorzenienie z historii młodych Polaków sprzyja ich szeroko rozumia-

\footnotetext{
${ }^{8}$ Nawiązując tu do słów Tadeusza Mazowieckiego z sejmowego exposé z 24 sierpnia 1989 r., w którym użył sformułowania „przeszłość odkreślamy grubą linią” (T. Mazowiecki, Przeszłość odkreślamy gruba linia. Przemówienie Tadeusza Mazowieckiego w Sejmie, „Gazeta Wyborcza” z 25 sierpnia 1989 r.).

${ }^{9}$ Zob. H. Świda-Ziemba, Urwany lot. Pokolenie inteligenckiej młodzieży powojennej $w$ świetle listów i pamiętników z lat 1945-1948, Wydawnictwo Literackie, Kraków 2003.
} 
nej europeizacji, której często akcentowaną właściwością są tendencje proemigracyjne ${ }^{10}$.

Współczesna młodzież dorastała w trakcie procesu starań i akcesji Polski do Unii Europejskiej. Omawiani przez mnie dzisiaj młodzi w 2004 r. mieli od 7 do 14 lat. Wydarzenia tamtych lat były naturalnym tłem okresu ich dziecinstwa i młodości. Nie ulega wątpliwości, że nie stanowiły one źródła szczególnych ekscytacji, niemniej jednak nie były dla nich zupełnie obojętne. Z biegiem lat stopniowo, obserwując też swoich nieco starszych kolegów z poprzedniej bliskiej generacji (czyli Europejskich Poszukiwaczy), uczyli się, jak z pojawiających się nowych europejskich możliwości korzystać. Wyjazdy wakacyjne, koncerty, festiwale czy nawet zwykłe zakupy w krajach Unii Europejskiej wpisały się do stałego repertuaru rozrywek młodych Polaków. Rosnaca popularnością cieszą się programy stypendialne, którym towarzyszy nie tylko poznawanie europejskich społeczeństw i specyfik ich kultur, lecz również rekonesans i zainteresowanie zagranicznymi rynkami pracy. Nierzadko wzmacniają je działania administracji i pracodawców różnych krajów europejskich, poszukujacych wykwalifikowanej kadry wśród wykształconej zagranicznej młodzieży - nie tylko zresztą polskiej. W tych obszarach europeizacja polskiej młodzieży wyraźnie zaznacza swoją obecność. Europejski rynek pracy dzięki jego legalnej dostępności traktują tak, jak pracę we własnym kraju. Przeprowadzka (z gwarancją pracy) na czas określony lub nieokreślony do Wielkiej Brytanii, Holandii, Niemiec czy gdziekolwiek indziej w ramach Wspólnoty nie jest nawet w pełni traktowana przez młodych jak emigracja. Przelot samolotem do dowolnego miasta Unii Europejskiej zajmuje niejednokrotnie mniej czasu niż podróż w Polsce. Niewątpliwie fakt życia w zjednoczonej Europie jest bardzo ważny dla współczesności dzisiejszej polskiej młodzieży, mimo że do nowych możliwości podchodzi ona w zasadzie prawie bezrefleksyjnie, traktując je jak coś oczywistego. Należy jednak pamiętać, że jest to dopiero druga taka grupa pokoleniowa w naszym kraju, a dynamiczne kształtowanie europejskości nadal jest liczącą się cechą jej sytuacji pokoleniowej.

\section{NIEUSTANNE PODDAWANIE NIESPOTYKANEMU DOTYCHCZAS, INTENSYWNEMU, WIELOŹRÓDLOWEMU WPLYWOWI BODŹCÓW ZEWNĘTRZNYCH}

W tym miejscu konieczna będzie dygresja ze świata neurobiologii. Ilość bodźców i informacji, które codziennie wchłania współczesna młodzież, zaczyna przekraczać możliwości adaptacyjne ludzkiego organizmu. Szczególnie należy tu podkreślić fakt, że interesujące nas pokolenie młodych, dziśs stopniowo

\footnotetext{
10 Jak sygnalizował CBOS w komunikacie z badań z końca 2013 r.: „wśród respondentów w wieku od 18 do 24 lat tylko co trzeci (36\%) odrzuca możliwość wyjazdu. Niemal co czwarty badany w tym wieku (26\%) deklaruje, że w przyszłości będzie starał się o pracę poza granicami Polski. Mniej więcej tyle samo (23\%) przyjęłoby ofertę takiej pracy, o ile by ją otrzymali. [...] stosunek młodych Polaków do emigracji może rodzić niepokój co do skali tego zjawiska w przyszłości” (CBOS, Poakcesyjne migracje zarobkowe. Komunikat z badań, BS/166/2013, Warszawa 2013).
} 
wkraczające w dorosłość, w całym swoim życiu, od samego początku doświadczało socjalizacyjnych wpływów świata zdominowanego przez rosnąca liczbę bodźców, bezustannie dostarczanych zmysłom. To pierwsze takie pokolenie $\mathrm{w}$ historii, nieznajacce i w zasadzie niepotrafiące sobie wyobrazić otaczających nas rzeczywistości bez telefonów komórkowych, komputerów, Internetu. Wydawać by się mogło, że to pokolenie ewolucyjnie przyzwyczajone (socjalizowane) do bezkresu informacji, jakie codziennie musi przetwarzać mózg.

Nadmiar informacji oraz silnych bodźców ma jednak negatywny wpływ na funkcjonowanie mózgu. Efektem jest na przykład rosnąca drażliwość i niecierpliwość oraz osłabienie zdolności analitycznego i refleksyjnego myślenia ${ }^{11}$. Uściślając, zaburzeniu ulega wewnętrzna równowaga organizmu (jego zdolność do czynnego utrzymania stałości środowiska wewnętrznego), którą Claude Bernard uznał za zasadniczą cechę żywego organizmu ${ }^{12}$. Aby ową równowagę (stałość środowiska wewnętrznego) utrzymać, w organizmie działają różne mechanizmy adaptacyjne. Główną rolę w ich generowaniu pełni układ nerwowy współczulny, a koordynowane przez ten układ procesy Watler B. Cannon nazwał homeostazą ${ }^{13}$. Homeostaza to stan równowagi ustrojowej - idealny stan organizmu - zrównoważony poziom nasycenia tlenem, temperatury ciała, pH krwi i płynów ustrojowych, ciśnienia itp. Nasz mózg dąży do utrzymania homeostazy, a jej zaburzenia „wywołuja szereg negatywnych reakcji ustrojowych. Wpływają na proces wzrastania, fizjologię rozrodu, sa przyczynami różnych endokrynopatii, zaburzeń metabolicznych, zaburzeń układu immunologicznego oraz chorób psychicznych" ${ }^{14}$.

Dążąc do homeostazy, ale jednocześnie dbając o przetrwanie, nasz układ nerwowy troszczy się zarówno o aktywację, pobudzenie do działań, jak i dezaktywację, przejście do stanu spoczynku, spokoju. Za pobudzenie do działania odpowiedzialny jest układ nerwowy współczulny, za odpoczynek i wyciszenie - układ przywspółczulny. Zwłaszcza ten drugi, w aspekcie interesujących nas zjawisk, jest szczególnie ważny, gdyż minimalizuje zagrożenia zaburzeń psychicznych, przywracając stan dezaktywacji organizmu.

Współczesna młodzież stale wystawiana jest i sama się wystawia na działanie ogromu szybko następujących po sobie bodźców. Telefony komórkowe, Internet i gry komputerowe to najlepsze przykłady, ale uzupełnia je również telewizja, agresywność reklam, tempo życia w mieście, pogoń za przyjemnościami itd. Gdy pojawia się nadmiar bodźców, wówczas dochodzi do stałego uruchomienia układu współczulnego. Działamy w trybie mobilizacji. Im więcej bodźców do nas dociera i zostaje przetworzonych, tym trudniej jest nam później się wyciszyć - odczuwamy stały stan napięcia lub jego głód. Nieskończo-

${ }^{11}$ Por. np. N. Carr, Ptytki umyst. Jak internet wptywa na nasz mózg, tłum. K. Rojek, Helion, Gliwice 2012.

12 J. Landrowski, Biologiczne mechanizmy stresu, w: A. Bilikiewicz et al. (red.), Psychiatria, t. 1: Podstawy psychiatrii, Wyd. Medyczne Urban \& Partner, Wrocław 2002, s. 179.

${ }_{13}$ Ibidem.

${ }^{14}$ B. Pawlaczyk, Rola hormonów w regulacji homeostazy organizmu człowieka, „Homines Hominibus" 6, 2010, s. 9. 
ność następujących po sobie bodźców działa jak narkotyk i zaburza niezbędna dla zdrowia psychicznego równowagę nastroju i przeżyćc ${ }^{15}$.

W sytuacji permanentnego informacyjnego przeciążenia mózg, nie mogąc przeanalizować bombardujacych go informacji, przechodzi w tryb awaryjny. Modyfikacji ulega funkcjonowanie kory przedczołowej - spada złożoność analiz, poziom empatii, tolerancyjnośćc ${ }^{16}$. „Korze przedczołowej powszechnie przypisywana jest odpowiedzialność za »funkcje wykonawcze«, obejmujące wyższej rangi kontrolę różnych aspektów procesów poznawczych oraz regulację zachowania. Tego typu "wykonawcze» aspekty funkcjonowania płatów czołowych czynią z człowieka jednostkę dostosowaną do społeczeństwa oraz obdarzona we własne sądy, wolę, rozsądek, osobowość i stosowne zachowania"17. Nadmiar bodźców, modyfikując czynności regulowane w korze przedczołowej, skutkuje efektami podobnymi do tych, obserwowanych u osób cierpiących na autyzm. Pojawiają się problemy z wyrażaniem emocji i komunikacją w relacjach interpersonalnych. Spowolnieniu ulega interpretacja myśli i uczuć osób, z którymi wchodzi się w interakcje. Słabnie umiejętność postrzegania zjawisk i procesów z cudzej perspektywy. Mimo sprawnego zapamiętywania nawet pokaźnej liczby informacji obniża się zdolność do wykorzystania ich w praktyce.

Współczesna młodzież wychowywana i dorastająca w czasach cywilizacyjnego skoku (rozwoju technologii komunikacyjnych) niestety bardzo często takie cechy posiada. To co nierzadko oceniamy jako złe wychowanie, jest efektem stałego bombardowania nadmiarem bodźców (pomijając tu wątki niepomyślnej, nieudanej socjalizacji $\left.{ }^{18}\right)$. Dzisiejsza młodzież potrafi doskonale odnajdywać się w wirtualnych przestrzeniach i umiejętnie poszukiwać oraz selekcjonować informacje, ale nierzadko nie umie (i nie chce!) poddawać ich refleksyjnej analizie. Ograniczenie zdolności refleksyjnego myślenia współczesnej młodzieży, generowane biochemicznie może być (między innymi) podłożem popularności zachowań moralnie złych - na przykład umieszczania w sieci filmików o znęcaniu się nad kolegami, któremu towarzyszy tym większe zadowolenie, im więcej osób je ogląda (liczba wejść), i ocenia (liczba lajków). Tu socjalizacyjna perswazja ma mniejsze szanse zadziałania, najpierw należałoby „naprawić mózg”.

Poza tym u osób przeciążonych nadmiarem informacji (nie tylko zreszta młodych, ale ich właśnie w znacznej mierze zjawisko to dotyczy) wydłuża się czas reakcji ${ }^{19}$. Coraz częściej w codziennych interakcjach zdarza się nam obserwować opóźnioną reakcję na zadane pytanie, a na udzielenie odpowiedzi musimy czekać jak w telewizyjnym przekazie satelitarnym - przeciążony nadmiarem bodźców mózg działa wolniej.

15 Por. N. Carr, op. cit.

${ }_{16}$ D. Morańska, M. Jędrzejko, Cyfrowi Tubylcy - socjopedagogiczne aspekty nowych technologii cyfrowych, Oficyna Wydawnicza Aspra-Jr, Warszawa 2013.

17 B. C. Jobst, B. C. MacDonald, Zaburzeniazachowania pochodzeniaczołowego, w: S. C. Schachter, G. L. Holmes, D. G. A. Kasteleijn-Nolst Trenite (red.), Padaczka. Aspekty behawioralne w teorii i praktyce, Wydawnictwo Czelej, Lublin 2009, s. 261.

18 Problem ten omawiam gdzie indziej (zob. W. Wrzesień, Modyfikacje..., passim).

19 Por. T. Klingberg, The Overflowing Brain: Information Overload and the Limits of Working Memory, Oxford University Press, Oxford 2008. 
Trudno w takim kontekście nie podać w wattpliwość popularnego od około dziesięciu lat (nie tylko w mediach) stanowiska zachwalającego współczesną młodzież jako efektywnych wielozadaniowców, wykonujących kilka czynności jednocześnie, a przy tym robiących takie wrażenie, jakby tworzyli nowa jakość i byli lepsi od konkurencji z innych pokoleń ${ }^{20}$. Byłbym ostrożny w optymistycznych ocenach technologicznych kompetencji współczesnej polskiej młodzieży. Owszem portale społecznościowe, gry komputerowe, aplikacje mobilne i internetowe czy zwykłe poszukiwania w Internecie, to ich pasje, lecz gdy obsługuja edytor tekstów, bazę danych lub arkusz kalkulacyjny, to okazuje się, że wcale nie sa w tych działaniach lepsi od starszych.

Nie sposób zaprzeczyć, że socjalizacja do nowoczesnych technologii, doświadczana od najmłodszych lat, może być (i jest) kapitałem kulturowym dzisiejszej młodzieży. Warto natomiast zwrócić uwagę na charakterystyczne dla miłośników komputerowo-telefonicznej rzeczywistości ograniczenia stosunków społecznych w świecie realnym, osłabienie i tworzenie nowych form (quasi-)więzi z grupami, w których uczestnicza, oraz nierzadko kłopoty z realizacja „normalnych” wzorów interakcji. Mimo zachwytów nad wynikami badań Centrum Badań nad Kulturą Popularną SWPS w 2010 r. ${ }^{21}$, uwypuklających pozytywne aspekty obecności nowoczesnych technologii komunikacyjnych w świecie życia codziennego dzisiejszej młodzieży, byłbym wielce ostrożny $\mathrm{w}$ formułowaniu, w moim przekonaniu, nieco przedwczesnych ocen.

Współcześnie wszyscy korzystamy z dobrodziejstw Internetu i telefonii komórkowej. W rzeczywistościach konstruowanych i zasiedlanych przez młodych doprowadzają one do dość szczególnych modyfikacji przestrzeni codzienności. Charakterystycznym przemianom ulegają przebiegi działań i interakcje w grupach społecznych, w których młodzież uczestniczy i które współtworzy. Cechą naszych czasów stało się konstruowanie jednej realno-wirtualnej rzeczywistości, gdzie płynność granic stwarza pozory ich braku. Nie tylko młodzieży towarzyszy dziś stały kontakt z tym, co żyje w sieci, jednakże dla młodych granice pomiędzy przestrzenią wirtualną a realną uległy rozmyciu. Dla dzisiejszej młodzieży to, czego mogą doświadczyć poprzez aktywność w sieci, jest tak samo ważne, jak doświadczenia w świecie rzeczywistym. Stałe kontrolowanie przebiegu informacji i włączanie się w jej obieg przekracza obszary komunikacji online, wkraczając do codzienności niemal we wszystkich możliwych sytuacjach. Rozmowy przez telefon komórkowy, odpowiedzi na SMS-y, przesyłanie zdjęć, filmów i komentarze na portalach społecznościowych w pracy, na ulicy, sklepach, w czasie rozmów, spotkań towarzyskich, lekcji, wykładów, jazdy rowerem czy samochodem (!) itp., w zasadzie nikogo już nie dziwia, stały się norma, a magii stałej komunikacji ulegają nie tylko młodzi. Oni jednak, współtworząc ten nowy komunikacyjny wielopłaszczyznowy subświat, prawie od początku swojego życia traktuja go tak, jak jeszcze niedawno traktowana była tylko realna rzeczywistość codzienności. W perspektywie zdecy-

${ }^{20}$ Zob. W. Wrzesień, Europejscy Poszukiwacze..., passim.

${ }^{21}$ M. Filiciak et al., Mtodzi i media. Nowe media a uczestnictwo w kulturze, SWPS, Warszawa 2010. 
dowanej większości dzisiejszej młodzieży niemal nie można być „tu” (w świecie rzeczywistym), nie wiedząc, co dzieje się „tam” (w świecie wirtualnym).

W tej zmianie pomogła jeszcze wspomniana promocja idei wielozadaniowości, w którą wielu chciało wierzyć, i to nie tylko młodych - jej urokowi ulegali też nauczyciele czy rodzice. Z tym że wielozadaniowość, tak często prezentowana jako pozytywna cecha współczesnej młodzieży, moim zdaniem, wydaje się, że jest raczej jej ułomnościa, wadą wygenerowana przez specyfikę naszych czasów. Nie ulega wątpliwości, że dzisiejsi młodzi potrafią wiele czynności wykonywać jednocześnie, ale niestety rzadko udaje im się w tej multiaktywności robić coś naprawdę dobrze. Najczęściej bowiem osoby podejmujące się kilku działań naraz mają trudności z koncentracją uwagi na jednym z nich. Paradoksalnie natomiast ci, którzy posiadają najlepszą umiejętność skupiania się, właśnie dzięki tej zdolności rzadko wykonują kilka zadań w tym samym czasie ${ }^{22}$. Co więcej, młodzi odczuwają zarówno przymus takich zachowań, jak i nierzadko prawdziwy psychiczny dyskomfort, gdy nie mogą ich realizować (np. sprawdzać, czy nie przyszły e-maile w czasie wykładu). Tu płynnie wkraczamy do przestrzeni trzeciego elementu pokoleniowej sytuacji współczesnej młodzieży.

\section{IV. ŻYCIE W ŚWIECIE ZRÓŻNICOWANYCH FORM UZALEŻNIEŃ I ULEGANIE IM}

Dzisiejsza młodzież to poszukiwacze, wpisujący się w nurt przemian charakterystycznych dla kultury konsumpcyjnego kapitalizmu, która tak modyfikuje dotychczasowe systemy norm, wartości i wzorów zachowań, aby skutecznie gwarantować maksymalizację zysku, przede wszystkim głównym graczom sceny ekonomicznej (i politycznej). Przedkładając łatwe nad trudne, proste nad złożone, szybkie nad powolne ${ }^{23}$, w połączeniu z dobrobytem (w czasach którego można pozwolić sobie na luksus niedorosłości) i chciwościa, tworzy zbiór szczególnych cech współczesności ${ }^{24}$. Znastolatyzowani dorośli i zdziecinniali młodzi ${ }^{25}$, tworząc społeczeństwa wyspecjalizowanych konsumentów, nieprzerwa-

22 Zob. D. M. Sanbonmatsu et al., Who Multi-Tasks and Why? Multi-Tasking Ability, Perceived Multi-Tasking Ability, Impulsivity, and Sensation Seeking, PLOS ONE, 23 stycznia 2013.

${ }^{23}$ Zob. B. R. Barber, Skonsumowani. Jak rynek psuje dzieci, infantylizuje dorostych i potyka obywateli, tłum. H. Jankowska, Muza, Warszawa 2008.

${ }^{24}$ Szeroko cechy kultury konsumpcyjnego kapitalizmu omawiam w innym miejscu (zob. W. Wrzesień, Europejscy Poszukiwacze..., passim).

${ }_{25}$ Nastolatyzacja to symboliczne podtrzymywanie przez dorosłych cech mile wspominanych z okresu młodości, ale przeniesionych do współczesności ich dorosłości. To podążanie za młodzieżowymi modami dla dorosłych i wykorzystywanie możliwości, na jakie pozwala dorosła niezależność, w maksymalizacji doznań w czasie wolnym i czasie zabawy oraz zaspokajanie potrzeb sztucznie tworzonych przez rynek dla dorosłych, którzy nie chcą do końca wydorośleć. Nastolatyzacja dorosłych to termin nawiązujący do infantylizacji Barbera, ale - w moim odczuciu - lepiej oddający sens interesujących nas cech współczesności. Myśląc o symbolicznej nastolatyzacji dorosłych, porównuję ich do starszych nastolatków, którzy przeważnie biologicznie są na tyle rozwinięci, że mogą konkurować z dorosłymi, natomiast proces osiagania przez nich dorosłości psychicznej jeszcze się nie zakończył. Potrafią zarówno beztrosko się bawić, jak i efektywnie pracować. Posiadaja już taki zasób wiedzy i kompetencji, że bez trudu odnajdują się w różnorodnych społecznych rze- 
nie przekonywani są o dobrodziejstwach płynących z nieograniczonych wręcz możliwości indywidualnego komponowania własnych światów. Szczególne miejsce w tym procesie zajęło podsycanie potrzeby stałego poszukiwania zmian i podążania za nimi. Konsumpcyjny kapitalizm umiejętnie przywrócił na pierwszy plan naszą naturę drapieżnika-myśliwego, nadając status niekończącej się dobrej zabawy nieustannym polowaniom - pogoni za nowymi doznaniami bez zbędnego przywiązywania się do zdobyczy. To, co się liczy, jest przed nami, a to, co już zdobyliśmy, szybko traci swój urok. W znacznej mierze mogło do tej przemiany dojść za sprawa specyfiki funkcjonowania naszego mózgu, której zawdzięczamy skłonność do uzależnień (niekończących się poszukiwań). Aby poszerzyć spektrum wyjaśnień pokoleniowej sytuacji współczesnej młodzieży, konieczne będzie tu przypomnienie kilku uwag o dopaminie i układzie opioidowym, których wpływ na przemiany współczesnych przestrzeni świata życia rodzinnego analizowałem w innym miejscu ${ }^{26}$.

Zadaniem dopaminy jest zarówno kontrola systemu przyjemności w mózgu, motywującego nas dzięki odczuwaniu zadowolenia i przyjemności do poszukiwań pożywienia, seksu czy narkotyków ${ }^{27}$, jak i ciagłość zachowań poszukiwawczych. Dopamina podnosi poziom pobudzenia i intensywność działań zorientowanych na realizację celu, utrzymując naszą motywację do wszelkiej aktywności i przetrwania w otaczającym świecie. Oprócz potrzeb fizycznych stymuluje też poszukiwania abstrakcyjnych idei. Generuje ciekawość oraz dostarcza energii do poszukiwań informacji. Obok dopaminy w generowaniu naszych skłonności do uzależnień ważną rolę odgrywa układ opioidowy mózgu, odpowiedzialny za odczuwanie przyjemności. Dwa wspomniane systemy dopamina i układ opioidowy uzupełniają się - dopamina stymuluje działania, a układ opioidowy nagradza odczuwaniem satysfakcji, które na krótko przerywa poszukiwania ${ }^{28}$. Dopamina jest silniejsza niż układ opioidowy, co powodu-

czywistościach. Bywają jednak - podobnie jak dzieci-dorośli u Barbera - zwolennikami prostych, łatwych i szybkich rozwiązań i bywają niecierpliwi. Równolegle, gdy dorośli odmłodnieli i różnice zaczęły niebezpiecznie się zacierać, to młodzież zdziecinniała. $\mathrm{Z}$ jednej strony zdziecinniała trochę z przekory, gdyż tak długo, jak istnieje, zawsze chciała od dorosłych się odróżniać, z drugiej - trochę z kalkulacji, gdyż w ten sposób można żyć wygodnie i „uciekać” przed odpowiedzialnością dorosłości. Oczywiście zdziecinnienia młodzieży, podobnie jak nastolatyzacji dorosłych, nie można odczytywać dosłownie. Młodzi zauważyli, że można być dorosłym i nie-dorosłym, a wcale nie dzieckiem. Można bawić się, można uczyć się i pracować, ale nie wkraczać w dorosłość „w starym stylu”, a nawet i w tę „nową, znastolatyzowana, wkraczać później i niechętnie. Ten zbiór cech charakteryzujący styl życia współczesnej dorastającej młodzieży to konsekwencja zarówno rozwoju kapitalizmu konsumpcyjnego i jego kultury, jak i realizowanych przez rodziców wzorów ról rodzicielskich. Szerzej powyższe procesy analizuję gdzie indziej (zob. W. Wrzesień, Europejscy Poszukiwacze..., passim).

${ }^{26}$ Zob. W. Wrzesień, Modifikacje..., passim.

${ }^{27}$ Odwołuję się tu jedynie do fragmentu specyfiki działania dopaminy, która „wytwarzana przez neurony dopaminergiczne jest głównym neuroprzekaźnikiem katecholowym w mózgu ssaków. Pobudzając swoiste receptory, dopamina bierze udział w regulacji różnych procesów, takich jak: utrzymanie postawy ciała i poruszanie się, zapamiętywanie, uczenie się oraz interpretowanie bodźców emocjonalnych” (J. Drożak, J. Bryła, Dopamina - nie tylko neuroprzekaźnik, „Postępy Higieny i Medycyny Doświadczalnej” 59, 2005, s. 405).

${ }^{28}$ K. C. Berridge, T. E. Robinson, What is the role of dopamine in reward: hedonic impact, reward learning, or incentive salience?, „Brain Research Reviews” 28, 1998, s. 309-369. 
je, że pragnienie poszukiwań jest silniejsze niż odczuwanie stanu satysfakcji. W efekcie tworzą się pętle dopaminowe - dopamina stymuluje ciagłość poszukiwań, nawet wówczas gdy zakończą się one sukcesem. Najlepszych przykładów dostarcza aktywność w przestrzeniach Internetu - często gdy znajdziemy poszukiwaną informację i tak wciąż kontynuujemy przeglądanie stron - nasz mózg nastawiony jest bardziej na oczekiwanie nagrody (poszukiwania), niż samo jej zdobycie (stan satysfakcji) ${ }^{29}$.

Żyjąc w świecie permanentnej wielobodźcowej stymulacji, stajemy się coraz bardziej pobudzonymi poszukiwaczami nowych satysfakcjonujących doznań, i... nie dostrzegamy naszego uzależnienia. Uzależnienia rozumianego jako przymus działania - nałogowych poszukiwań informacji, robienia zakupów, posiadania gadżetów, opalania w solarium, biegania, ćwiczeń w klubie fitness, aktywności na portalach społecznościowych, poszukiwania porad, ale też sukcesu, rywalizacji, gier itd. Zróżnicowane formy uzależnień o charakterze behawioralnym stają się ważnymi elementami naszej codzienności i towarzyszą nam we wszystkich jej przestrzeniach ${ }^{30}$.

Takimi nałogowymi poszukiwaczami (konsumentami) jest też współczesna młodzież, ulegająca wpływom kultury konsumpcyjnego kapitalizmu, która dzięki umiejętnemu marketingowi ${ }^{31}$ i postępującej cywilizacyjno-technologicznej globalizacji uniformizuje (uzależniając) wzory funkcjonowania w wielu rzeczywistościach współczesności. Poprzednia grupa pokoleniowa w Polsce (Europejscy Poszukiwacze) w zasadzie nie pamiętała rzeczywistości PRL i była pierwszą taką nowa bliska generacją w naszym kraju. Dzisiejsza młodzież jest natomiast pierwsza (od wielu lat) wychowaną w czasach znaczacego cywilizacyjnego skoku, którego niezamierzonym efektem ubocznym stały się przestrzenie potencjalnych uzależnień. Możemy obserwować je wszędzie, zarówno w świecie pracy, jak i w świecie czasu wolnego czy tak ważnej dziś zabawy, a mówiąc bardziej ogólnie - we wszystkich obszarach tzw. indywidualistycznych poszukiwań własnego miejsca w świecie lub jak kto woli - własnej oryginalności.

Wszyscy dziś ulegamy podobnym wpływom, lecz to, co interesujących nas młodych wyróżnia, to fakt, że nie mają oni alternatywnych punktów odniesienia, żadnej możliwości porównań - nie znają świata „sprzed”, nie wiedza, jak

${ }^{29}$ S. Weinschenk, Why We're All Addicted to Texts, Twitter and Google, 2012, www.psychologytoday.com.

${ }^{30}$ Są też przedmiotem badań medycznych i psychologicznych, wśród których ostatnio zauważalnie wzrasta zainteresowanie uzależnieniem od Internetu i telefonu komórkowego, będąc równolegle odpowiedzią na zapotrzebowanie „rynku” stosownych terapii.

${ }^{31} \mathrm{~W}$ tym wykorzystującemu silne techniki manipulacyjne, np.: neuromarketing, marketing partyzancki, lokowanie produktu, marketing wirusowy, cool hunting, reality advertising itp. (zob. m.in. G. Zaltman, Jak myśla klienci. Podróż w gtąb umystu rynku, Forum, Poznań 2004; J. Zweig, Your Money and Your Brain: How the New Science of Neuroeconomics Can Make You Rich, Simon \& Schuster, New York 2007; K. Zięba, Granice etycznych praktyk marketingowych w zakresie nowych form promocji, w: L. Garbarski (red.), Kontrowersje wokót marketingu w Polsce - tożsamość, etyka, przyszłość, Wyd. WSPiZ im. Leona Koźmińskiego w Warszawie, Warszawa 2004, s. 297-306; J. W. Wiktor, Reklama-między perswazja a manipulacja. Etyczne kontrowersje wokót komunikacji marketingowej, w: L. Garbarski (red.), op. cit., s. 289-296. 
żyło się bez Internetu i telefonów komórkowych, bez bogactwa otaczających zewsząd bodźców.

Ostatnio z tego też między innymi względu zarówno w pracach naukowych, jak i tekstach publicystycznych zwraca się uwagę na wykorzystywanie nowoczesnych technologii do budowania własnej tożsamości przez dzisiejszych młodych - definiowanie siebie poprzez technologie ${ }^{32}$. W moim przekonaniu jeszcze ważniejsze $\mathrm{w}$ procesie kształtowania tożsamości społecznej pokolenia współczesnej młodzieży jest uzależnianie się od technologii i subświatów, jakie tworza. Nowoczesne technologie (zapewniające trwały dopływ nowych bodźców) stają się dla młodych wszechobecnym niezbędnikiem, a jego brak (np. zgubienie telefonu lub utrudnienia w dostępie do Internetu) wywołuje drażliwość, niepokój, a nawet stany lękowe czy ataki panikii ${ }^{33}$. Ten typ objawów każdy terapeuta uzależnień bez trudu potrafiłby jednoznacznie zdiagnozować. My natomiast, przyjmując perspektywę teorii pokoleń, przede wszystkim musimy pamiętać, że taki po prostu jest świat dzisiejszej młodzieży, świat ich młodości. Wyjątkowy, ponieważ przeżywany tylko raz w życiu i procentujący w przyszłości mniej lub bardziej wyrazistymi cechami pokoleniowości, których dziś nie sposób jeszcze prognozować.

$$
* * *
$$

Aktualne, zróżnicowane i selektywne rozważania na temat wykorzenienia z historii, nieustannego poddawania wieloźródłowemu wpływowi bodźców zewnętrznych oraz uleganiu licznym nowym formom uzależnień o charakterze behawioralnym mają bardzo spolaryzowany charakter - od zachwytów po totalną krytykę. Dzisiaj (z wyjątkiem problemu leczenia uzależnień) nikt nie jest $\mathrm{w}$ stanie rozstrzygnąć, czy są one naprawdę dobre, czy też złe. To zresztą nie zadanie socjologii. Wskazane i wstępnie przeanalizowane jako zbiór (a nie wybór) cechy są przede wszystkim „tą” sytuacją pokoleniowa (,ich własną), która doświadcza dzisiejsza młodzież. Warto będzie się jej efektom w najbliższych latach uważnie przyglądać, gdyż odnoszę wrażenie, że pierwszy raz od wielu lat obserwujemy wyraźne znamiona zupełnie nowej jakości młodzieżowej pokoleniowości, i to nie tylko w regionalnych wcieleniach (na które w niniejszym tekście zwracałem uwagę), lecz również w wymiarze globalnym ${ }^{34}$.

dr hab. Witold Wrzesień

Profesor Uniwersytetu im. Adama Mickiewicza w Poznaniu witoldww@gmail.com

${ }^{32}$ Por. H. Gardner, K. Davis, The App Generation: How Today's Youth Navigate Identity, Intimacy, and Imagination in a Digital World, Yale University Press, New Haven 2013.

${ }^{33}$ N. Ogińska-Bulik, Uzależnienie od czynności. Mit czy rzeczywistość?, Difin, Warszawa 2010; C. Guerreschi, Nowe uzależnienia, Salwator, Kraków 2010.

${ }^{34}$ Tak wyraźnie odróżniająca się rzeczywistość własnej pokoleniowości doświadczali np. w czasach hipisowskich (1967-1969) przedstawiciele Baby Boomers w Stanach Zjednoczonych i niektórych krajach Europy Zachodniej, brytyjskie pokolenia czasów klasycznej epoki punk (1976-1980) czy clubbingu w okresie tzw. Drugiego Lata Miłości (1988-1989). 


\section{SOME REMARKS ON THE GENARATIONAL SITUATION OF CONTEMPORARY POLISH YOUTH}

\section{Sum mary}

The generational situation of contemporary Polish youth is quite special and is the result of changes both on the macro scale, which include the dominance of the culture of consumer capitalism, the rapid progress of civilisation (mainly the development of communication technologies), globalisation, accession to the EU and on the micro scale - unique, and intense changes in patterns of socialisation.

The generational situation of young Poles (born 1990-1997), presumably representing the first cohorts of a new generational group, has three prime components: 1) a societal break with historic roots; 2) the continual, intensive, multi-source, but until now rare, impact of external stimuli; and 3 ) the fact that they live in a world with a variety of addictions and become dependent on them. In my opinion we should in the future observe carefully all the features discussed in this article, because for the first time in many years we have seen clear signs of a completely new quality in the sense of identity of the young generation, not only in their regional incarnations, but also on a global scale. 
